\title{
JÁNOS BARANYAI DECSI AND HIS ADAGIA
}

\author{
Gyula PACZOLAY \\ H-8201 Veszprém, P.O. Box 158, Hungary
}

\begin{abstract}
The oldest extant Hungarian proverb collection - one of the first ones in EastCentral Europe - can be found in the Adagiorum Graecolatinoungaricorum Chiliades quinque published in Bártfa in 1598. It was based on a 1574 Basel edition of the Adagiorum Chiliades by Erasmus, including collections of Gilbert Cousin and others, too. The 4827 Hungarian entries of the Adagia include about 900 proverbs, part of them in common use today, others known in certain regions while some fell into oblivion. About 100 of them can be found in about 30 books (e.g. Fables of Aesop by G. Heltai) and letters of earlier date.

The author, János Baranyai Decsi, headmaster of the Székelyvásárhely school and graduate of the Strasbourg Academy also wrote a travel description, a book of comparative law, poems in Latin and Greek, translated Sallust into Hungarian, wrote on Hungarian runic writing, the history of his time (he died in 1601) survived in manuscript form.

Keywords: Hungary, Baranyai-Decsi, Erasmus, Bártfa (Bardejov, Slovakia), Székelyvásárhely, Transylvania, Strasbourg, Wittenberg, Hungarian, 16th century, proverbs, paremiology, adagia
\end{abstract}

\section{INTRODUCTION}

Four hundred years ago, in 1598 , a small $\left(12^{\circ}\right) 444$ page book, entitled $A d a-$ giorvm Graecolatinovngaricorvm Chiliades quinque: Ex Des. Erasmo, Hadriano Iunio, Ioanne Alexandro, Cognato Gilberto et aliis optimis quibusque Paroemiographis excerptae, ac Vngaricis prouerbiis, quoad eius fieri potuit, translatae, studio ac opera succisiua Ioannis Decii Baronij - in short Adagia - was printed by the Klöß Press in Bártfa, Sáros County in Upper Hungary (BD-1). This book includes the oldest extant collection of Hungarian proverbs. As stated in the introduction to the readers, it was intended to teach wisdom and to provide help in public speaking. An earlier, lost collection by Miklós Siklósi is mentioned in the introduction but nothing more is known about it.

Earlier English, Arabic (Al-Maidani, a. 1124), Danish, Dutch, French, German, Italian, Spanish, Swedish and Turkish (Mahmut al-Kashgari 1073-1074) collections are known, while just preceding it, a Czech (Červenka-Blahoslav, a. 1571) and following it a Polish one (Samuel Rysiński, 1618) were made. The first Estonian and Ukrainian collections date back to later years of the 17th century, the 18th century saw the appearance of the first Finnish, Russian, Serb and Slovak collections, while Bulgarian and Rumanian ones are known from the 19th century. 


\section{THE AUTHOR}

The author of the Adagia was János BARANYAI DECSI CSIMOR (Ioannes Decius Barovius or Baronius). He was born about 1560 in the Transdanubian country town (oppidum) Decs - now a village in Tolna County. Following two Wittenberg graduates, Ádám Tordai and Péter Laskai Csókás, from 1593 on until his death on May 15, 1601 (BGy), he was director - called rector - of the "minor" school (particula) the predecessor of the later college - of Székelyvásárhely, a country town (oppidum) in Transylvania. The town was named Marosvásárhely in 1616, when the status of free royal borough (libera regiaque civitas) was granted to it by Gábor Bethlen, Prince of Transylvania.

He studied first at the Protestant school of Tolna (about 15 kilometers from Decs), founded in 1549 by Imre Szigeti, a Wittenberg graduate, where Bálint Tolnai Fabricius - (wo studied from 1573 to 1575 in Wittenberg) author of several Hungarian poems and one of the best Hungarian Hebraists of that time - was his teacher and also where the translation (from Greek into Hungarian) of the Ecclesiasticus (Wisdom of Jesus the son of Sirach) - printed in Kolozsvár in 1551 - was made. Tolna was host of the national assembly in 1463 and 1513, and was under Turkish rule from 1543 on. About one third of the homes were inhabited by Turks. As a senior student (tógátus) he studied at the colleges of Debrecen and Kolozsvár. In 1587 - as a tutor of the son Ferenc of Farkas Losonci Bánffy, counsellor of the Prince of Transylvania - he left for Wittenberg, the town of Luther and Melanchthon, where a Hungarian coetus was founded in 1555. He became a member of it on July 26, 1587. From 1589 on he studied at the Academy of Strasbourg. He was introduced to professor Johann Jakob Grynaeus (1543-1617) in Basel in a letter of May 18, 1587, written by the rector of the Mezôtúr school, Miklós Tolnai Katona, who was a student of Grynaeus in Heidelberg in 1584. (SzA pp. 129-130, 165-166). His dissertation on philosophy was prepared under the guidance of Johann Ludwig HAWENREUTER (1548-1618), professor of medicine and philosophy - who also taught physics - at Strasbourg, and was in addition the author of a collection of Latin proverbs and quotations, published in 1573 (JLH). On the 18th June 1592 in Strasbourg he met Albert Szenci Molnár (DL, p. 9) but soon after returned to Kolozsvár in Transylvania. After spending some time there the post of the director of the Sárospatak College was offered to him, but - following the advice of his friends at the court - he declined to accept it and became the director of the school in Székelyvásárhely.

In the years preceding 1598 Decsi had published three works in Latin and one in Hungarian. He had written poems in Latin and Greek while some of his works remained in manuscript.

The description of his travel from Bonchida - via Székelyvásárhely, Brassó, Bákó, Lwów, Warsaw, Danzig, Stettin and Berlin to Wittenberg, in Latin prose - the Hodoeporicon itineris Transylvanici ... (Wittenberg 1587), is dedicated to Farkas Losonci-Bánffy (BD-2). It is one of the first travel descriptions written by a Hungarian, preceded, for example by the Hodoeporicon itineris Constantinopolitani by Paulus Rubigallus (Wittenberg 1547), and followed by the Hodoeporicon itineris Argentora- 
tensis by Georgius Deidrich (Strasbourg 1589), and by the Europica Varietas written in Hungarian by Márton Szepsi Csombor (Kassa 1620). It was discovered in 1890 by József Koncz in the Teleki Library in Marosvásárhely, where the only known copy can be found. It was studied and translated into Hungarian by Lajos TARDY in 1980 (TL). The travel description itself is preceded by an introduction outlining his philosophy of history.

His thesis on philosophy, the Synopsis Philosophiae (BD-3), covering mathematics, physics, metaphysics, ethics, politics and economics, was dedicated to his patron, Chancellor Farkas Kovacsóczy.* It was published first in Strasbourg in 1591 (BD$3 / 1$ ) and reprinted - in a smaller size - in Wittenberg in 1595 (BD-3/2). One copy of the former is now in Prague and one of the latter in Budapest. An English manuscript translation of it (BD-3/3) was found in the British Library in London by György GÖMÖRI (GGy). A short description of the thesis was given by János ERDÉLYI in 1858 (EJ).

The Syntagma institvtionvm ivris Imperialis ac Ungarici (BD-4) is a comprehensive, 800 page comparison of Hungarian and Roman imperial law, aimed at the harmonization of Hungarian law (a similar process having taken place in Germany and France previously), including corresponding recommendations, and a collection of 600 legal proverbs (BD-5). On the initiative of Chancellor Farkas Kovacsóczy and other friends in the Court in Transylvania it was prepared in Strasbourg, under the guidance of Dionisius Gothofredus. In the letter of the 5th February, 1592, Decsi wrote to Professor J. J. Grynaeus in Basel (SzA) that he hopes, it will be just as important in law, as the Theologiae Sincerae Loci Communes De Deo Et Homine by István SZEGEDI KIS (SzK) - printed five times in Basel - proved to be in theology. It was dedicated to Prince Zsigmond Báthori and was printed by Gáspár Heltai in Kolozsvár in 1593. Today 28 complete copies and 14 damaged (to a greater or lesser extent) of it can be found in libraries in Europe, some include a picture of the author. It was studied in detail by Professor János ZLINSZKY (ZJ-1). It may be mentioned in this connection that in 1596 Decsi complains in one of his letters written to Ferenc Hunyadi, the prince's doctor, that not only was a due appreciation of this important work missing, but that less than half of the expenses which he incurred were paid. Then he asked for permission to leave Transylvania together with two of his students (BD-6). Maybe it was refused, he did not leave the country until his death.

$\mathrm{He}$ translated into Hungarian the two main works of the Roman historian Sallust (86-36 BC), the Bellum Catilinae, dealing with corruption in Roman politics and the Bellum Jugurthinum, exploring the origins of party struggles. The book is entitled: Az Caivs Crispvs Salustivsnac ket Historiaia (BD-7), it is dedicated in Latin to Zsigmond Báthori and in Hungarian to its readers, "to the benefit of people of all

* He studied in Padova and France, wrote a work in Latin on the administration of Transylvania (KF) and - sharing the fate of other dignitaries - was killed in prison in 1594 for failing to support the anti-Turkish policy of the Roman Catholic Prince Zsigmond Báthori, of whom it was recorded that he did not even touch a "heretic" book. The confessor - and diplomatic envoy - of the Prince was Alfonso Carillo, a Spanish Jesuit. 


\section{E R A ${ }^{n z} S M I$ ROTER O D A M I}

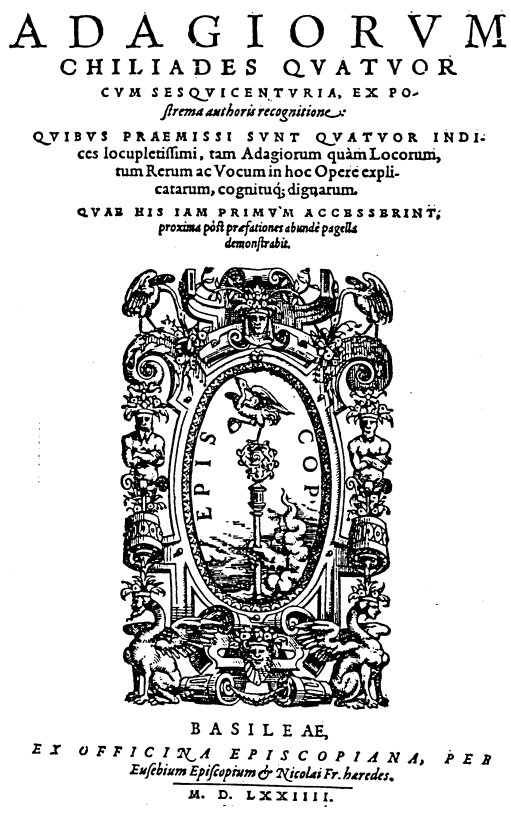

Fig. 1

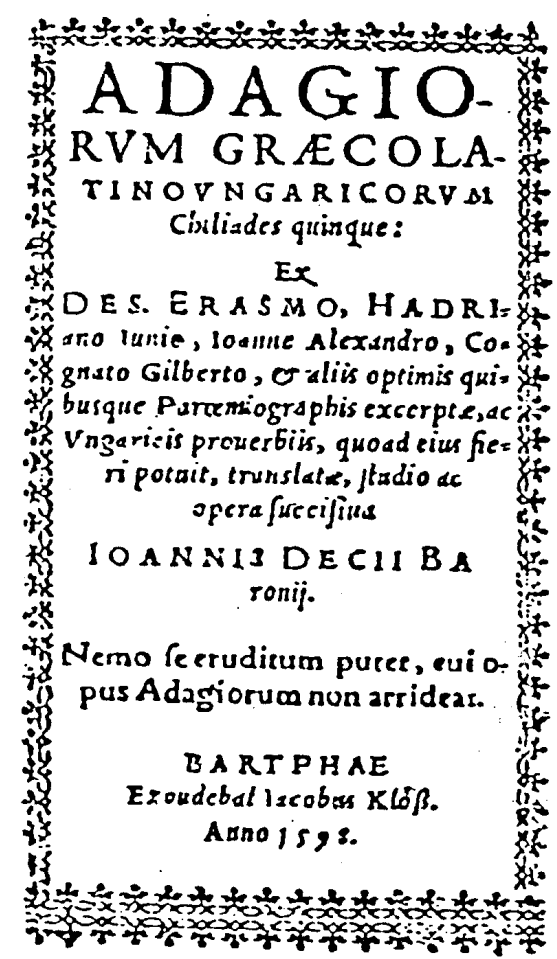

Fig. 2

sorts". It includes references to contemporary events and was published in Szeben in 1596. He did not get even the cost of binding for it. It was discovered in Eger in 1813 as reported by Ferenc Kazinczy. In 1979 a study of it was written by Ágnes KURCZ (KÁ). A reprint of the unique complete copy now known was published in 1979.

Based on documents of the Gyulafehérvár archive and oral history, for example, talks with Péter Miskolci, the Veszprém Calvinist priest on the surrender of the city, and with Mehmed, the captured bey of Lippa, he prepared a manuscript history of Hungary of the years 1592 to 1598 in good and clear Medieval Latin, entitled Commentarii de rebus Vngaricis. Originally it was intended to form part of a complete history of Hungary "following the truth, in short and clearly" (vere, breviter et pure). Together with the works of Ferenc Forgách (1530-1577), Pál Gyulai (born in 1550, killed in 1592) and István Szamosközy (1570-1612) it is an important source of Hungarian history. The first part of a copy of the manuscript was found in 1798 by Márton György Kovachich, the second in 1866 by Ferenc TOLDY. He published the Latin texts in the same year (TF). It was translated into Hungarian and published with notes and an introductory study in 1982 by Péter KULCSÁR (BD-8). It may be mentioned that the official historian of the court of Zsigmond Báthori was the Italian Gian Michele Bruto. 
The manuscript of his call to Prince Zsigmond Báthori to resolutely continue the war against the Turks, the Oratio Ioannis Decii Baronii ad Serenissimum Principem ... Sigismundum ... De bello adversus Turcam fortiter et constanter persequendo (1598) was found recently in Zagreb and was published - together with a Hungarian translation by Ibolya TAR - in 1990 (BD-9).

His essay on Hungarian runic writing written for the Rudimenta priscae Hunnorum linguae of János Telegdi (Leiden?, 1598?) can be read for example in the $M a$ gyar Athenas by Péter BOD (1766) (BD-10). Five of his letters, written between the 31st May, 1590, and the 5th February, 1592, from Strasbourg to Professor Johann Jakob Grynaeus (1543-1617) in Basel have been preserved to our day. Their Latin texts together with notes and Hungarian summaries were published in 1989 by András SZABÓ (SzA).

$\mathrm{He}$ also wrote one Greek and several Latin poems, mainly to fellow students such as Miklós Debreceni Tankó (1588, Greek), János Tolnai Szabó (1588, Latin), Demeter F. Eszlári (1589, Latin), Zsigmond Újfalusi Pécsy (1589, Latin), Mihály Forgách (1589, Latin) and András Reichmund (1591, Latin) who were concluding their studies in academies abroad. A 12 line dedication in verse to Farkas Losonci Bánffy precedes the text of his Hodoeporicon (1587, Latin). His "Elegia" is included along with the poems of professors and other students, like Gallus Rhormannus and Georgius Deidricus from Teke, Transylvania (they were students of Professor Hawenreuter), and Ioannes Turnouius from Poland - in Manes Sturmiani. It was published by friends and students after the death of Johann Sturm (1507-1589), founder of the Strasbourg Academy and rector of it from 1537 on (Strasbourg 1590) (BD-11). A short Latin poem of his, to be presented below (pp. 285-286), is found in his Syntagma institvtionvm ivris (Kolozsvár, 1593) (BD-4).

It is supposed by András SZABÓ (SzA, p. 142) that Decsi is probably the author of the anonymous work, a lecture presented in Wittenberg entitled Oratio De Constitvendo Ivdice Controversiarum Religionis Pontificae Atque Reformatae ... Scripta et Habita ab Vngaro Veritatis Asserendae Studioso, published by Grynaeus in Basel in 1591, printed in English translation in the same year in London (BD-12). It was also supposed by Imre Lukinich, based on several identical proverbs in a Hungarian poem on the Turkish rulers, (written in 1597 "in an empty convent in the town of Seklers") and in the Adagia, that the poem itself may be the work of Decsi. According to Béla Holl this is not a sufficient proof (TCs).

Some additional details on the life and activities of János Baranyai Decsi can be found in the papers of Ferenc TOLDY (TF), József KONCZ (KJ), Emma BARTONIEK (BE) and János ZLINSZKY (ZJ-2). Concerning the school of Tolna the corresponding chapter of the book of Géza KATHONA (KG), about the Hungarian coetus in Wittenberg and its various (e.g. publishing) activities the works of Géza SzABÓ (SzG) and Miklós AszTalos (AM) can be recommended. Additional data on the Székelyvásárhely Particula and the Marosvásárhely College can be found in the book edited by Pál NAGY (NP-1). He is the author of an article on Baranyai Decsi as well (NP-2). 


\section{THE ADAGIA}

The Adagia starts with a dedication to the patron of the author, György Varkucz, of whom nothing is known. It is followed by an introduction to the readers (16 pages) and at the end the 20 line Latin poem by Ioan Balogus (János Tolnai Balog) "In Zoilvm seu in obtrectatorem linguae Hungaricae" can be found.

The number of printed copies was most likely small, about 300 or so and the book soon became a rarity. At present four complete copies and 10 damaged (to a greater or lesser extent) are known altogether, five in Budapest (two complete), one complete in Késmárk, three in Kolozsvár (one complete) and one each in Marosvásárhely, Nagyszeben, Nyirkáta and Sárospatak (RMNY-815). It is likely that Albert SZENCI MOLNÁR got a copy with no or a damaged title page preparing his Hungarian-Latin Dictionary (1611, SzM-1). The Reformed bishop of Gyulafehérvár, István Geleji Katona, author of Magyar grammatikácska (A short Hungarian grammar, 1645) was unaware of it. Péter Bod, the author of the first Hungarian encyclopaedia of literature (Magyar Athenas, 1766) following the reference of Albert SZENCI MOLNÁR (SzM-1, Introduction) gave an incorrect title (Libellus Adagiorum LatinoUngaricorum), date and place of publication ("while the author stayed in Argentina", i.e. Strasbourg) (BP), indicating that he either did not see it, or had only a copy without title page. In 1828 one copy of it is known to have been on sale at Pál Burián's second-hand bookshop in Buda (TF, p. XIII). János ERDÉLYI publishing his first collection of Hungarian proverbs in 1851 (EJ-1) openly admits that "I did not see this book". - A report of a damaged copy of the Adagia was given in 1850 by Mór BALLAGI calling it an unknown collection (BM-1), then it was specified as that of Baranyai Decsi by the owner, Professor József LugOssy in 1851 (LJ). In 1866 three slightly damaged copies of it were known to Ferenc TOLDY, one each in the libraries of the Colleges of Sárospatak and Kolozsvár and one in the property of Academician József LugOssY (TF, p. XIV).

For long the proverbs of Baranyai Decsi were attributed partly to Albert Szenci Molnár (1611), and mainly to Péter Kis-Viczay (1713) or even to later sources. It was only in the second volume of Mór BALLAGI's proverb collection (1850) (BM-2) and in the revised 1862 edition of János ERDÉLYI's collection (EJ-2) that a number (though by far not all) of Baranyai Decsi's proverbs were sourced properly. It may be noted that 340 texts, marked Prov. by Albert Szenci Molnár had been published by Márton KISBÍRÓ in 1882 without mentioning that their ultimate source is the collection of Baranyai Decsi (KM). In the same year 90 texts of the Adagia were published by Nándor KÖNNYE (KN). The comprehensive collection of Ede MARGALITS (ME, 1897) presents very few proverbs of Decsi. In the collections of Gábor O. NAGY (ON-1, 1966) and Gabriella VöÖ (VG, 1989) and in the monolingual Hungarian dictionaries of Mór BALlagi (BM-4, 1873) and of the Hungarian Academy of Sciences (ÉSz, 1959-1962) there are no references to earlier occurrences of individual proverbs.

In 1978 a reprint edition of the Adagia was published by the Department of Hungarian Language of the Budapest Loránd Eötvös University. (BD-1, Reprint.) 


\section{THE MODEL OF THE ADAGIA}

As proved by Vilmos TOLNAI in 1911 (TV-1) it was a large size $\left(2^{\circ}\right) 1701$ page volume including detailed Latin explanations of Latin and Greek quotations and proverbs, entitled: Des. Erasmi Roterodami Adagiorvm chiliades qvatvor cvm sesquicentvria, ex postrema authoris recognitione, published in Basel in 1574. In this book, following the work of ERASMUS (1466/1469-1536), the adagia of Hadrianus Junius (d 1575), Johannes Alexander Brassicanus (d 1539), Johannes Ulpius, Gilbert Cousin (Cognatus) (d 1567), Ludovicus Caelius Rhodiginus, Polydorus Vergilius, Petrus Godofredus, Charles de Bovelles, Adrianus Turnebus, Gulielmus Gentius, Iunius, Canterus, Giselinus and Melchior Neipeius are also presented (EAd).

In this connection it may be mentioned that - according to the findings of Ádám DANKANITS - in Transylvania the rank order of the most popular foreign authors in the 16th century was: Melanchthon, Erasmus and Cicero (DÁ-1). He also found that in the accessible libraries in Transylvania at present there are about 50 copies of Apophtegmatum Libri, Epitome Adagiorum or Chiliades Adagiorum by Erasmus (DÁ2). One small collection of the adagia of Erasmus was also published in Hungary in Brassó in 1541 (EEp).

There are now two known copies of the Adagia of Erasmus which include some manuscript additions of Hungarian proverbs. A 1508 Venice Aldus edition of Adagiorum Chiliades Tres ac Centuria in Budapest includes a few Hungarian proverbs inscribed between 1510 and 1540 by Tamás Pelei, canon of Gyulafehérvár, reported by Ottó B. KelÉNYI in 1940 (KO). A copy of the 1559 Basel Frobenius edition of Adagiorvm Chiliades Des. Erasmi Roterodami qvatvor cvm sesqvicentvria, now in Sárospatak, once belonged to Ferenc Szárászi. He studied in Wittenberg and Heidelberg between 1584 and 1586 and presented the book to Mihály Decsi (of whom nothing is known) in 1604. He died in 1610. According to the study of Imre CZEGLE, on the first 600 pages of the volume Szárászi provided 1743 of the 2001 items with Hungarian equivalents before 1604. It was was also found that 1231 of these inscriptions are identical with the corresponding data of Baranyai Decsi and in 512 cases there are some differences (CzI). It seems that these additions are based on the work of Baranyai Decsi, in some cases improving on them.

\section{THE STRUCTURE OF THE ADAGIA}

The structure follows that of Erasmus. As a rule, every chilias (thousand) includes ten centuria, which are divided into ten decads, each comprising ten items numbered from 1 to 10. Decsi omits the explanations of his model, often puts the Greek sentence on the first place, combines several Latin quotations of similar meanings (e.g. in 1.3.7.10* there are one Greek and 26 Latin, in 1.5.6.7. two Greek and five Latin items), occasionally omits one item, makes changes in the order, and adds one or more Hungarian equivalents or a Hungarian translation to each.

* The first number is the Chilias, the second the Centuria, the third one the Decas, and the fourth the serial number inside the Decas. 


\section{THE CONTENT OF THE ADAGIA}

The book includes 4795 items. The deviation from the 5000 suggested by the title (chiliades quinque) is explained by omissions. Apart from some minor ones, e.g. Centuria IX and X are missing from Chilias I, just as Decas IX from the Centuria IX of Chilias V, etc. On the other hand, there are some repetitions, e.g. there are two Decas III in Chilias III, Centuria VI. The total number of Hungarian data is 4827. Sixteen items include two, one (3.4.7.7) three, and one (3.10.10.10) four Hungarian equivalents. On the other hand, several of them are repeated in different items. E.g. "Vgyan azon bakot nyúzza" (He is stripping the hide of the same buck) can be found ten times, "Bagolyis biró házában" (Even the owl is a judge in his house) seven times, "Sok lúd diznót gyöz" (Many geese overcome a pig) five times, etc.

From among the 4827 Hungarian items about 900 or so qualify as proverbs or proverbial comparisons. Sometimes the Hungarian equivalent of the - usually equally short - Latin text is simply given by one word, e.g. "vándorló" (wanderer), "javallani" (to recommend) or by an attributive construction, e.g. "rövid szó" (short word), "erös ember" (strong man), "hitvány ok" (poor reason), "székely fortély" (Sekler trick), etc. Many simple sentences are also found that cannot be considered proverbs, like "Ismerik ök egymást" (They are known to each other.) 2.5.5.10., "Az ió hirnek örülni" (To be glad on getting a good news.) 5.2.10.2., "Görög és Deák nyelvet tudni." (To know the Greek and the Latin languages.) 5.9.6.1. etc. Others are quotations or aphorism, often translations of the corresponding Latin or Greek term.

\section{THE SOURCES OF THE ADAGIA}

According to Vilmos TOLNAI (TV-1) 3438 Latin items were taken from Erasmus, 1349 from different authors of the same 1574 volume; the author(s) of seven of them is unknown, and one of them: "Procul Buda claudo" (Messze Buda sánta embernek - Buda is far away for a lame man.) 2.5.3.3. was translated from Hungarian into Latin by Decsi. We found that - apart from the items taken from the collection of Erasmus, constituting the 1.1.1.1.-4.10.9.5., 5.8.4.8.-5.8.8.6. and 5.9.7.4.-5.10.2.10. parts - most (546) of the remaining titles, (e.g. 5.1.1.1.-5.6.9.1., 5.10.6.2.-5.10.9.1. and 5.10.10.1.) derive from the collection of Gilbert Cousin (Cognatus), comprising 1810 items in the 1574 Adagiorum Chiliades volume. It may be added that in this book the Greek word $\Sigma_{l} \kappa \varepsilon \lambda \varsigma_{\varsigma}$ or the Latin Siculus means the Non-Greek original inhabitants of Sicily. This was "translated" by Decsi as "székely" (Sekler), being the name of the ethnic Hungarians living in the eastern part of Transylvania. E.g. in 2.4.10.4. the Hungarian equivalent of "Siculus emphacisat" is presented as "No mind fel veßi az ßékely, valami egy tetünél iob." (A Sekler picks up anything of more value than a louse.) This example also shows the fortunately broad treatment of equivalence by Decsi. 


\author{
CHILIADISI.

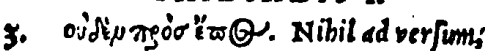 \\ Más biró iárára. Nibil ad chordam, idem

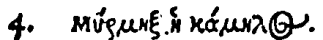 \\ Formica Camelus, Vgy illenck òzue \\ mint az eb faz matska. \\ f. Os fublinere, Szòmét valakinck bé, \\ 6. Dare verba, Meg czalni. \\ 7. Addere manum, Valakit meg czuffol: \\ ni. Circumtondere comam, idem. \\ 8. Fucum facere, Meg c7alni.

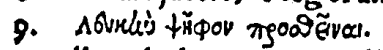 \\ Albo calculo notare, Iauallani. \\ Creta notare, idem. \\ 20. Carbone notare, K.írhozcatni. \\ Theta prafigere. Obelo ac flellis notare. \\ Vngue notare, idem.

\section{DECAS IIII.} \\ 7. Calculum reducere, \\ Meg vonni az bìat. \\ 2. Stilum vertere, \\ Víǵa hazudni az mit irtál. \\ 3. Omne puntum ferre, Mindenektool i2 \\ ualtarni. Cunctorum calculis probari, ide

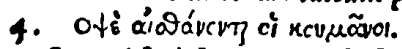 \\ Cumaniforó fapiunt, Kefó lứcue.

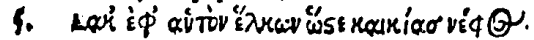

CBNTVRIA III!.

Mald attrabens ad fefe vt. Cacias nubes, 8 maga gờoóz magának nyaualyát.

6. Olleum in auricula ferre, Hizelkòdnl.

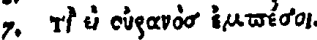

Quid fi colcum ruat?

Ott fylz ue àhól nem kellene fylned.

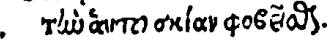

$\checkmark$ mbram fuam metuere, Arnyékától f̧̣lni Mufcas metuil pretervolitantes, idem.

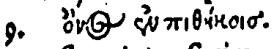
A finus inter fintids.

Kolni.

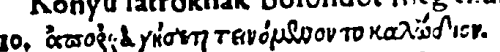

Abrampilur funis nimium tendendo,

El tơrik az k'ez ị ha fólótcêb meg vont

zakk.

DBCAS $V$.

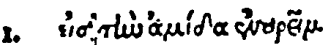

In matellam immeicre,

Sák meg lelte fóltriát.

2. ré̉

Rifus lonicus, Negédós neuet $\{g$.

3. TÉ

Rifus Megaricus, Farkas neuesfęg.

Rifus Sardonius, idem.

4. rézwoxi@. Rifus Chius, Faitalanßag.

C 5 s. Quics

Fig. 3

Most of the Hungarian data of the Adagia likely derive from Decsi's own collection, but at least a hundred can be located in more than 30 Hungarian works published before 1598. As a source the Száz fabula ... Esopusbol (One hundred fables of Aesop) by Gáspár Heltai (Kolozsvár 1566) appears most frequently, followed by the comedy Theophania by Lőrinc Szegedi (Debrecen 1575), Balassi Menyhárt árultatásáról szóló komédia (Comedy on betraying by Menyhárt Balassi) (Abrudbánya 1569), Salamon és Markalf históriája (The story of Solomon and Marcalphus) (Kolozsvár 1577), Aesopi Phrygis fabulae by Gábor Pesti (Vienna 1536), and the works of Bálint Balassi, Péter Bornemissza, Ferenc Dávid, Mihály Sztárai, etc. may also be mentioned. Others are included in contemporary documents, quoted e.g. in the Erdélyi magyar szótörténeti tár (A historical dictionary of Hungarian vocabulary from Transylvania) by Attila Szabó T. (1975-1998), in 16th century letters, like the correspondence of István Báthori, Prince of Transylvania. These and the appearance of many of them in later independent - including regional - collections of Hungarian proverbs lend authority to the data of Baranyai Decsi.

It is evident that some data are translations of the corresponding German proverbs. Sometimes the meaning of the Hungarian item does not correspond to that of 
the Latin one, but agrees with a German proverb found in the collection of Sebastian FrancK, entitled Sprichwörter, Schöne, Weise, Herzliche Clugreden unnd (!) Hoffsprüch published in 1541 in Franckenfurt am Meyn (SF), or in another German collection. As an example, the Latin text of item 1.3.3.2. is "Pecunia obediunt omnia" (Anything obeys money), while the Hungarian equivalent of Baranyai Decsi reads: "Az ki nád közöt üll, Bintén ollyan sipot czinál, az minemüt akar" (One sitting among the reeds can make a whistle of his own choice.), literally the same as "Der in roren sitzt, schneidt jm. Selbst pfeiffen wie er wil" (SF p. 86v). An exact German but not Latin equivalent exists e.g. of "Gazda nélkül vet számot" (He calculates without - considering - the host) 5.9.6.7., and of "Az ki mézet akar enni, meg öllye elöb az méhet" (He who wants to eat honey should first kill the bees.) 3.3.5.9. (Note: Until fairly recently getting the honey involved killing the bees.)

The German word Spitz, meaning "top, peak" - rarely heard now as a loanword in Hungarian - appears in several proverbs (1.1.2.9., 1.4.9.4., 2.7.1.2., etc.). It was also found by Erzsébet ForGÁCH in the Hungarian text of the Chronica of Gáspár Heltai, published in 1575 (FE).

Hungarian translations of the Latin texts - instead of equivalents - are certainly often found. Some examples are: "Aequalitas non parit bellum" - Az egyenlöség nem támazt hadat. (Equality does not engender war.) 4.2.9.9., "Homo homini lupus" - Ember embernek farkassa. (Man is a wolf to man.) 1.1.5.6., "Sale et sole nihil utilius" - Nints sem̃i haznosb az Napnál s az sónál. (There is nothing more useful than sun and salt.) 4.8.6.7., "Virum malum vel mus mordeat" (also in Greek) - Az gonoz embert még az Egéris meg marja. (A wicked man is bitten even by a mouse.) 1.7.1.5., etc. In the process of folklorization of quotations, as the literary sources fall into oblivion, only one of the above quoted items became later a genuine Hungarian proverb: "Ember embernek farkassa" (Man is a wolf to man.).

\section{THE FOLLOW-UP TO DECSI'S PROVERBS}

Albert SZENCI MOLNÁR (1574-1634) too - in addition to Dresden and Heidelberg - studied in Wittenberg and Strasbourg, where he was likewise a student of Professor Hawenreuter and according to his diary, quoted earlier, he once met Baranyai Decsi there. His Hungarian-Latin dictionaries are also important sources of Baranyai Decsi's proverbs.

Adding a few 17th century proverbs, SZENCI MOLNÁR has selected and included about 400 "usitatiora proverbia", i.e. common proverbs of Decsi's Adagia in the second and third editions of his Hungarian-Latin dictionaries, published in Hanau in 1611 (SzM-1), and in Heidelberg in 1621 (SzM-2), respectively. He quoted his source exactly in the introduction: "Inspersi praeterea et usitatiora Proverbia Vngarica cum correspondentibus Adagiis Latinis. Ea autem selegi ex Libello Adagiorum Latino-Ungaricorum Cl. Viri Joannis Decii Baronii P.M. quem ante multos annos Argentinae adolescens observanter colui." (SzM-1, Quoted from the introduction of the first, Latin-Greek-Hungarian part.) 


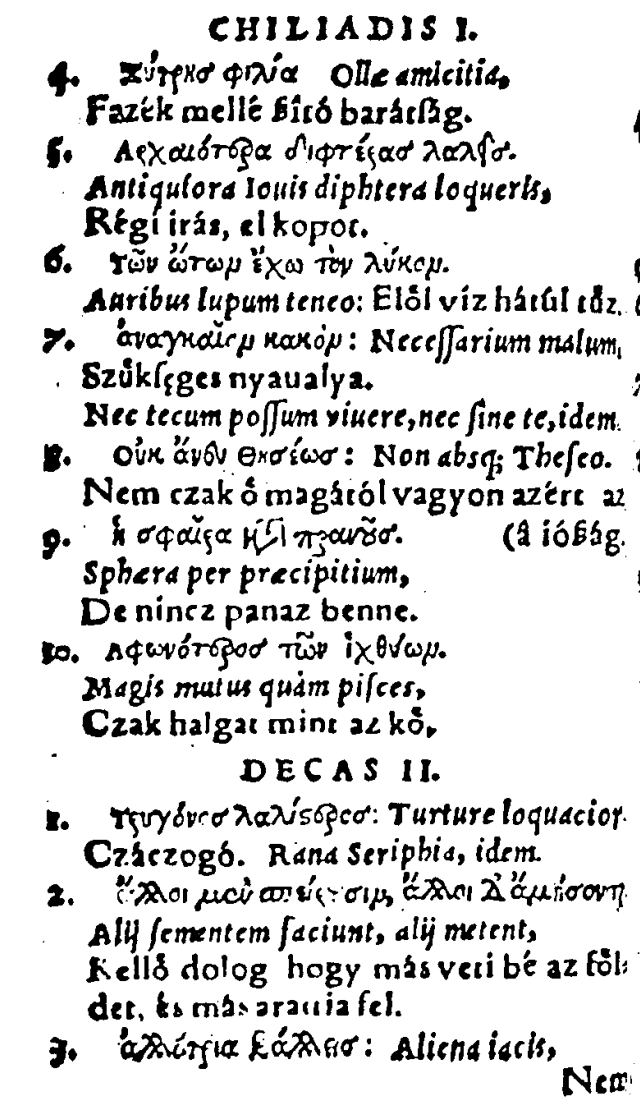

\author{
CENTVRIA IIII. \\ Nem íl veced az kotzkáh

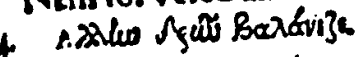 \\ Aliam quercusm exeutes \\ Marusis kéry, nám vgyan rcism bok: \\ al mint egy Wr borara. (gyel. \\ Relinque ruces: Ne gyermekeskodd=
}

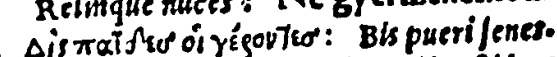

Mindenvén embernde 1 fárába Gal az

7. Sexagenarios de ponte deiiecter (cies

El kōliek immár ók arról.

crambe bis pofita mors,

Czak azon bakor ny hzzz.

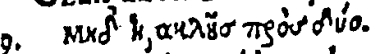

Ne Hercules quidem aduerfu duos.

Sokltad diznór gyóz.

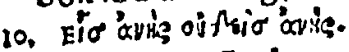

$\checkmark$ nus homo nullus homo,

Egy fa nema crdó. A finus inter equos, id

DECAS IIL

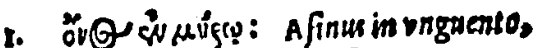

lgen iller samárs vórỏs nyereg. .

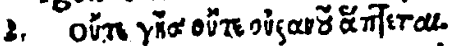

Neq; calum neq; terram attingit,

Oly tauol vagyon tólle mine 22 Egh

22 fóldsol.

C 2

Fig. 4

SZENCI MOLNÁR sometimes - for the better - slightly changed Baranyai Decsi's texts. They are occasionally conciser and closer to the current wording. For example Decsi wrote "Szemérem az futás, de hasznos" (1.8.3.4.), while Szenci Molnár's text reads "Szégyen a futás, de hasznos" (SzM-1.257/1, SzM-2.290/2), which is identical with the modern wording. These proverbs were also included in the revised edition, supplemented by German equivalents (SzM-3) (Nürnberg 1704) and the later ones, revised by Ferenc PÁPAI PÁRIZ and Péter BOD (PPB) (Nagyszeben, 1767, 1782), too.

In the National Széchényi Library in Budapest there is a 17th century manuscript, written in Transylvania by an unknown Protestant author, entitled Fasciculus Vocabulorum, Sententiarum et Adagiorum (FV). In the first part of it there are proverbs of Baranyai Decsi - together with Latin equivalents -, evidently taken from the third, Heidelberg 1621 edition of Albert SZENCI MOLNÁR's Dictionarium UngaricoLatinum (SzM-2), followed by those taken directly from parts of Decsi's Adagia with some additions, omissions and changes. In the orthography $c z$ is replaced conse- 
quently by $t s$. A number of Baranyai Decsi's proverbs are found in the proverb-play Actio Curiosa (AC, c. 1678) and a lot of them have found their way - partly through the dictionaries of Szenci Molnár - into common textbooks of the 18th and 19th centuries, like the Syntaxis Ornata by Ferenc Pomey (1745 etc.), the Phraseologia of Ferenc WAGNER (WF) and also the collections made for schools by István CSELKÓ (CsI) and Ferenc VERSEGHY (VF). In addition to oral transmission these printed texts must have also contributed considerably to the spread of Decsi's 16th century proverbs.

Also using the dictionaries of Szenci Molnár, even more items of the Adagia got into the second Hungarian collection of proverbs, the Selectiora Adagia LatinoHungarica in gratiam et usum Scholasticae juventutis collecta by the Lutheran priest of Kassa, Péter KIS-VICZAY. It was printed in 1713 by the Press of the City of Bártfa, working then in Kassa (KV). In this book there is no reference to the source of the proverbs and some of them were versified. The collection of Pál KovÁCs (KP, 1794) and several others also omit such references.

The collections of Baranyai Decsi and Kis-Viczay were first compared by Mór BALLAGI in 1882 (BM-3). A new look at Baranyai Decsi's work with some corrections of Ballagi's findings was made by Vilmos TOLNAI. He reported about this in the first part of his inaugural lecture on proverbs at the Hungarian Academy of Sciences on the 22nd March 1909 (TV-2) and in a paper mentioned previously (TV-1). A short assessment is found in the first part of Gábor O. NAGY's posthumous work on the history of the research into Hungarian phraseology, published in 1977 (ON-2, pp. 15-21) as well.

Decsi's proverbs in the 20th century. A review of Decsi's proverbs shows that at least a hundred of them are common proverbs today with the same or nearly the same wording as 400 years ago. Some examples are: "Küczin az bors de erös" (Pepper is small but hot.) 3.8.8.8. - "Olczó húsnak hig az leve" (A cheap meat yields a lean broth.) 2.8.4.7. - "Nem akarásnak nyögés vége" (Unwillingness ends in groaning.) 2.5.1.5. - "Jó pap hóltíg tanúl" (A good priest learns until death.) 1.6.8.3. - "Ió töt helyében iót ne váry" (In return for a good deed do not expect good.) 2.5.8.3. - "Sok lúd diznót gyöz" (Many geese overcome a pig.) 1.4.2.9. - "Oly meßße tölle, mint Mako Ierusalemtöl" (It is as far from it, as Makó - a town in Hungary - is from Jerusalem.) 3.4.3.3. - "Szemérem (today: szégyen) az futás, de haznos" (Running away is a shame but it is useful.) 1.8.3.4. - "Iob ma egy veréb, hogy nem mint hólnap egy tuzok" (A sparrow today is better than a bustard - i.e. a large bird - tomorrow.) 2.9.1.5.

Mainly into this category belong 35 European proverbs of Baranyai Decsi known currently in Europe in 28 to 54 languages, most of which can be traced back to Greco-Roman, Biblical or Medieval Latin sources (PGy-1). Some examples are: "Egyik kéz az másikat mossa" (One hand washes the other.) 1.1.3.8. - "Aiandék lónak nem kel à fogát nézni" (One should not look at the teeth of a gift horse.) 4.4.9.6. - "Csak addíg nyujtozzál, az míg az lepel ér" (Stretch yourself as far as the cover reaches.) 2.5.3.7. - "Ugyan nem árúlok ám én sákban matskát" (I do not sell a cat in a poke.) 5.5.2.4., etc. 
A few proverbs are also found in the neighbouring Slavonic languages (PGy-2), for example: "Az sok Bába közöt à gyermek is el ßokot vezni" (Among many midwives the child is often lost.) 2.6.9.2. - "Ne hány borsót az falra" (Don't throw peas on the wall.) 4.7.4.6. - "No meg hólt az gyermek s el költ az komaság" (The child has died, the godfathership has ended.) 2.7.9.10.

About 85 proverbs became regional ones, known now only in certain regions of the Hungarian language area. They can be found in one or more of the collections made in Bakonyalja, Drávaszög, the Northern Csángó area (in Moldavia in Romania), Háromszék, Hét, Karcag, Kéménd, Kórógy, Magyaró, Szatmár, Szeged, etc. Some examples are: "Hires eperyre nem kel kosárval menni" (You need not take a basket to collect famous strawberries.) 5.2.1.3., - also found in Turkish. "Elég egy kö ßáz variúnakis." (One stone is enough for - frightening - a hundred crows.) 5.6.10.3. (This proverb is also found in Turkish, Persian, Tamil and Malayalam. - PGy-3.) "Az ki Wráual pöröl, Isten annak oruossa" (He who quarrels with his master, has only - God as a doctor.) 1.1.8.2. and "Addíg hámcz az hárs fát, míg hámlik" (Peel the lime tree until it peels.) 3.4.1.10. - meaning the same as the now comon "Strike the iron while it is hot." - This proverb is also found in the Chronica by Gáspár Heltai, printed in Kolozsvár in 1575, quoting the commander Pál Kinizsi, urging his soldiers to attack in 1494. It appeared recently in the collection, made in the village of Magyaró in Transylvania, in the form: "Addig hántsad a hársat, amíg hámlik" (ZsJ, p. 98, No. 11), and also in a collection of Sekler proverbs as "Akkor hántsd a hársot, mikor hámlik" (SNG, p. 7, No. 29).

Finally there are a number of proverbs in the Adagia that have since fallen into oblivion. Some examples are: "Igen illik, mint az bot az tegezbe" (It fits there like a stick in a quiver. - i.e. it does not fit at all.) 1.7.3.4. - "Fogas ebnek való az czont rágás" (Chewing of bones is - suitable only - for dogs with teeth.) 1.5.8.8. - "Minden hituán lövö nilára vet" (Every bad archer blames his arrow.) 1.6.1.3. - "Én nem tudhatom, ha töké auagy túrós étek" (I can't decide whether it is a pumpkin or a curdy paste - i.e. I have not the faintest idea about it.) 3.2.3.8. - "Az ki variat akar löni, nem pengeti iját" (One intending to shoot a crow will not twang his bow.) 3.4.10.7. "Had morogion varga Pál, czak ió talpát czinállyon" (Let Paul the cobbler grumble, until he makes good soles.) 4.1.5.2., and so on.

\section{PROVERBS ABSENT FROM THE ADAGIA}

The Adagia includes most of the known old Hungarian proverbs, and for the great majority of them this is the oldest record. Only a few are missing, like "Akármind perseld az ebet nem lészen szalanna benne" (Anyhow you roast a dog, you get no lard from it) recorded in 1575, a common proverb today in the form of "Kutyából nem lesz szalonna" (Out of a dog there will be no lard). Gabriella Vöó has 141 references to it (VG-168/514). Another, now little known example may be "Az ellőtt nyilat nehéz visszahozni" (It is hard to bring back an arrow shot) of which 
we have now only one reference from Transylvania (VG-197/25). It is known in eight Turkish languages (BU-1933).

The absence of some old proverbs from the Adagia is explained by the fact that they appeared only later in Hungarian. For example "Nem mind arany, ami fénylik" (All that glitters is not gold), or "A kákán is csomót keres" (He looks for a knot even on the $/ \mathrm{bal} / \mathrm{rush}$ ) were first recorded in 1613 only.

In some cases in the Adagia there are only the exact Latin equivalents of some missing proverbs. Their translations which are common proverbs now, were unknown then as proverbs. In these cases Baranyai Decsi provides an explanation of their meanings or gives a different equivalent sentence. Some examples are: "Bis dat qui cito dat" 1.6.10.10. (Who gives quickly, gives twice.). Decsi's corresponding Hungarian text translates: If you want to do something good to somebody, do it quickly. Nowadays the exact translation of the Latin text: "Kétszer ad, aki gyorsan ad" is a well-known proverb. "Saxum volutum non obducitur musco" 3.4.6.8. (A rolling stone is not covered with moss.) Decsi explains as: He that changes schools too often can hardly be a good student - and - One can hardly get rich, who often changes his place. Other similar examples: "Nemo propheta acceptus est in patria sua" (No prophet is accepted in his own country.) 5.5.5.7. - "Piscis primum a capite foetet" (Fish stinks from the head at first.) 4.2.9.10. - "Una hirundo non facit ver" (One swallow does not make a spring.) 1.6.4.1. In these cases 1598 is a "terminus post quem" for the corresponding Hungarian versions.

\section{NOTES ON THE HUNGARIAN LANGUAGE OF THE ADAGIA}

The language and grammar of the Adagia, decided most probably by the printer, has certain characteristics worth dealing with briefly.

The definite article preceding nouns beginning with a consonant is in general but not always $-a z$, instead of $a$, e.g. "Egy $a z$ szoba $a z$ kemencével" (The room and the stove are one item.) 1.1.1.1. Both $a$ and $a z$ can be found e.g. in "Szeretné à hasznot, de fút $a z$ munkától" (He would like to have the gain, but escapes working for it.) 4.1.3.3.

The assimilation of the suffix -val, -vel (meaning with) - a standard practice now - often does not take place, just as in the language of the Csángós in Romania, e.g. "Sem Istenvel, sem embervel nem gondolni" 5.9.5.9. - instead of Istennel and emberrel. Examples of assimilation also occur.

Instead of nyáron, télen, (in summer, in winter) we find nyárban, télben, e.g. "Az ki nyárban nem gyüjt, télben agebül bánkodik" 5.8.8.5.

In some words instead of the standard $i$ phoneme, the vowel $\ddot{u}$ is found: üdö, hüsz, tü, etc., and instead of $e$ there is an $\ddot{o}$ : szöm, jótött, györtya. However, not all the close $e$ 's become $\ddot{o}$, as found in the present Szeged dialect, e.g. we find ember (5.9.5.9.) instead of embör. (These disappear in the dictionaries of Albert Szenci Molnár and in later collections.) 
Some words have since fallen into oblivion, like mony (egg, now: tojás) 4.1.1.5., eh (liver, now: máj) 5.1.1.5., turba (a money bag that could be closed with a key, a Turkish loanword in old Hungarian) 2.9.5.4., közköpölködik (plots, fondorkodik) 2.2.10.9. - The word minem occurs fairly often, it means simply nem (i.e. not or no) 5.3.6.1., and instead of elromlott (became bad) we read: el roszúla in 5.6.5.9., and lesesködni instead of leselkedni in 5.4.3.10.

If in a proverb of our day the word "kutya" (dog) is included, then in the corresponding one in the Adagia "eb" is found (1.6.1.8., etc.), meaning the same. Four hundred years ago the meaning of kutya was "a small eb". The meaning of hitvány is "rossz" (bad), that of jámbor - referring to humans - is "jó", i.e. good (2.5.7.7., 5.9.5.10., etc.). $-K i$ is now used only in connection with men (meaning who), then it could also refer to animals (2.4.10.5.) and inanimate objects, like a coach (4.8.10.4.) or even a country (1.5.1.2.).

The Hungarian word is "too" is always written in one word with he preceding one, e.g. bagolyis "the owl too" 1.5.10.3., on the other hand, the verbal prefix is always written separately in the texts of the Adagia, e.g. ki szöktek (4.6.3.5.).

The vowel preceding the letter $l$ is always long, e.g. hóltig tanúl (1.6.8.3.), hólnap (2.9.1.5.), as pointed out by Gábor TÖRÖK in 1954 (TG). In the comparative of adjectives after a vowel, instead of $-b b$ we always find $-b$, like job "better" (2.9.1.5.), vakmeröb "bolder" (4.5.2.7.) etc.

As a rule the 16th century Protestant orthography (KI) was used: $c z=$ English $c h$ in choose $=c s$ in modern Hungarian $=c z$ in Polish, $-t z=$ English $t s=c,-s$ (in some cases) $=$ French $j=z s$ etc. In some words examples of $t s=$ English $c h=c s$ in modern Hungarian also occur (e.g. in most cases we find matska "cat", but maczka also appears.)

\section{FIDE DEO, DIFFIDE TIBI ...}

Let's conclude this paper with a scarcely noticed little Latin poem of Baranyai Decsi, included in his legal study, the Syntagma institvtionvm ivris Imperialis ac Vngarici (BD-4). These six lines present a short summary of Decsi's practical philosophy, his code of conduct in the last decade of the 16th century Transylvania, under the rule of Prince Zsigmond Báthori.

The Latin text and its English translation - based on the Hungarian translation by László KREDICS - follow:

Fide DEO, diffide tibi, fac quae tua, castas

Funde preces, paucis utere, magna fuge,

Multa audi, dic pauca, tace abdita, disce minori

Parcere, majori cedere, ferre parem.

Tolle moras, mirare nihil, contemne superbos,

Fer mala, disce DEO vivere, disce mori. 
In English prose:

Trust God, don't be conceited, do your duty, Have sincere requests, little should suffice you, amass nothing,

Hear much, say little, keep the secret, teach patience to the young, To yield to the stronger, tolerate the companion,

Do not procrastinate, do not muse, despise the haughty, Suffer the bad, learn to live for God, prepare for your death.

\section{SUMMARY}

The first collection of Hungarian proverbs was published in Bártfa in 1598 in the book entitled Adagiorum Graecolatinovngaricorum Chiliades quinque (Adagia), based on a 1574 edition of the Adagiorum Chiliades of Erasmus including the collections of some other Latin paroemiographers (for instance Gilbert Cousin, providing 546 titles for Decsi) too. It was one of the first proverb collections in East-Central Europe.

The humanist author, János BARANYAI DECSI (1560-1601), - a graduate of the Strasbourg Academy - is also the author of a Latin travel description, a dissertation on philosophy, a comprehensive comparative study of Hungarian and Roman imperial law, including a collection of 600 Latin legal maxims. He translated the two main works of Sallust into Hungarian and wrote Latin and Greek poems. The history of Hungary from 1592 to 1598 remained in manuscript.

His Adagia includes 4827 Hungarian items comprising about 900 proverbs including proverbial comparisons. About one hundred of these can be found in Hungarian books, documents and letters written before 1598, most of them in the One hundred fables of Aesop by Gáspár Heltai (Kolozsvár 1566), and the comedy Theophania by Lórinc Szegedi (Debrecen 1575). Some of them are translations of the Latin or Greek texts or of the corresponding German proverbs found e.g. in Sebastian Franck's collection (1541).

About one hundred of Decsi's proverbs are common proverbs today, like "Sok lúd disznót győz" (Many geese overcome a pig), "Olcsó húsnak híg a leve” (A cheap meat yields a lean broth), "Nemakarásnak nyögés a vége" (Unwillingness ends in groaning), "Jobb ma egy veréb, mint holnap egy túzok" (A sparrow today is better than a bustard tomorrow) etc. About 35 of these are widespread European proverbs, like "Kéz kezet mos" (Hand washes hand), "Ajándék lónak ne nézd a fogát" (Do not look at the teeth of a gift horse). A few have equivalents in Slavonic languages, like "Borsót hány a falra" (He throws peas against the wall), others in Slavonic and Turkic languages, like "Híres eperre nem kell kosárral menni" (You need not take a basket to collect famous strawberries). Some of Decsi's proverbs are now known only in particular regions of the Hungarian language area, e.g. in Transylvania, i.e. they became regional proverbs, like: "Addig hántsd a hársat, amíg hámlik" (Peel the lime tree until it peels), quoted from 1494 and found e.g. in a recent collection in 
Magyaró (Transylvania). Some of the proverbs have since fallen into oblivion, like "Úgy illik, mint a bot a tegezbe" (It fits like a stick into a quiver.)

Hundreds of Decsi's proverbs were included - sometimes in a conciser form, closer to the present one - in Albert SZENCI MOLNÁR's Hungarian-Latin dictionaries (Hanau 1611 and the following editions). Partly through these they got into the subsequent Hungarian proverb collections, like that of Péter KIS-VICZAY (1713), and textbooks for schools and so - in addition to oral transmission - these dictionaries have contributed much to the spread of these proverbs in the Hungarian language area.

Decsi's collection contains most of the old Hungarian proverbs, the majority of those which appear missing in fact emerged in Hungarian only later, e.g. in the 17th century.

\section{LITERATURE}

AC Actio Curiosa:

Gaude, avagy Csernél Istvánnak beszélgetése. (Gaude, or the talk of István Csernél.) (c. 1678). KARDOS, Tibor (ed.): Régi magyar drámai emlékek. (Old Hungarian dramatic plays.) (Vol. 2.). Akadémiai Kiadó, Budapest 1960, pp. 354-396. (A play rich in proverbs.)

AM AszTALOS, Miklós:

Wissenschaftliches Leben in der Wittenberger Ungarischen Gesellschaft im 16. Jahrhundert. - Ungarische Jahrbücher 1930, pp. 128-133.

BD-1 BARANYAI DECSI, János:

Adagiorvm Graecolatinovngaricorvm Chiliades quinque: Ex Des. Erasmo, Hadriano Iunio, Ioanne Alexandro, Cognato Gilberto et aliis optimis quibusque Paroemiographis excerptae, ac Vngaricis prouerbiis, quoad eius fieri potuit, translatae, studio ac opera succisiua Ioannis Decii Baronij. Bartphae. Excudebat Iacobus Klöß, 1598. - (18)+(1-127)+128-424+(2) p. - 12 - (RMNy-815).

Dedicated to: Magnifico Domino Domino Georgio Varkvcz (p. 2), - Praefatio ad lectorem (Benevolo Lectori S.P.D.) 16 pp. - Adagia p. (1)-424, - In Zoilum, Seu In Obtrectatorem Linguae Hungaricae (a poem in Latin) by Ioan. Balogus (p. 425).

Reprint: Loránd Eötvös University, Fontes ad historiam linguarum populorumque Uralensium 5., ELTE BTK Department of Hungarian Philology, Budapest, 1987. (With a short introduction in Hungarian and German by József MOLNÁR).

Praefatio ad lectorem. Hungarian translation of the Preface by Ferenc CsONKA. - In: JP pp. 810818. Hungarian translation of János Tolnai Balog's poem "In Zoilum” by István TóTH, in the same volume pp. $515-516$.

BD-2 DECSI CSIMOR, János:

Hodoeporicon itineris Transylvanici, Moldavici, Russici, Cassvbii, Masovici, Prvssici, Borussici, Pomerani, Marchici \& Saxonici, exantlati 1587 a Generoso et Magnifico Domino, Dn. Francisco Banfilosoncio Ad Illvstrem et Magnificvm Dominvm Dn. Wolphgangvm Banfilosoncivm Parentem, Consiliarum Jllustrissimi Principis Transilvaniae Sigismundi Bathori de Somlio, \& Comitem Comitatis Dobocensis, Dominum in Banfi-Hvniad, Nagifalv, Bonczhida, \&c. Scriptum per Johannem Cz. Deczivm. - Ex Typographia Simonis Gronebergij, Witebergae, MDLXXXVII (1587) 18 fol. $4^{\circ}$ (RMK-III. 764) (Hungarian translation: TL-1, KSI, partial translation: TL-2).

Hungarian translation of the introduction: KULCSÁR, Péter: Baranyai Decsi János magyar históriája (1592-1598). Európa Könyvkiadó - Helikon Kiadó, Budapest, 1982, pp. 16-20.

BD-3/1 DECSI, János:

Synopsis Philosophiae In Privatvm Memoriae Svbsidivm Thesibvs Et Velvt Aphorismis quibusdam comprehensa, \& ad disputandum proposita in Academia Argentinensi: Praeside Ioanne Lvdovico Havvenreutero, Medicinae \& Philosophiae Doctore atque Professore. Respondente \& Authore Ioanne Deczio Vngaro. Haec studia adolescentiam alunt, senectutem oblectant, secundas res ornant, aduerlis perfugium atque solatium praebent, delectant domi, non impediunt foris, pernoctant nobiscum, peregrinantur, rusticantur in quibus tractandis, humanum est, candide lector, honestos 
conatus beneuolentia prosequi, non reprehensione. - Argentorati (Strassburg), Excudebat Antonius Bertramus, MDXCI (1591), -35 fol. $-4^{\circ}$. - (RMK-III. 815).

BD-3/2 DECSI, János:

Synopsis Philosophiae in privatvm memoriae svbsidivm thesibvs et velut Aphorismis quibusdam comprehensa \& ad disputandum proposita in Academia Argentinensis. Praeside Ioanne Lvdovico Havvenreutero, Medicinae \& Philosophiae Doctore atque Professore. Respondente \& Authore Ioanne Deczio Vngaro. Per Praelum Vvelacianum, Witebergae, Anno MDXCV (1595) -63 fol $-8^{\circ}$ - (RMK-III. 864).

The paragraphs on corruption (Politica $§ \S 67-68$. Causae corruptionis Monarchiae) were published in 1866. (TF, pp. LXII-LXIII.).

BD-3/3 DECSI, János:

A breife veiw (sic!) of philosophy compiled in certaine positions and as it were aphorisms for the private helpe of memory and propounded for disputation in the University of Argentinum ... Johannes Deczius ... These studies be nurces (!) of Youth, the delightes of age, the crowne of faelicity (!), the helpe in adversity, comfortable at home, not troublesome abroad, companions of our lodging, fellowes in our Jeorneys (!), abinding with us together in the country: In the handling whereof (gentle reader) lett humanity lead you to favour and not to carp at my honest endevour. Manuscript in The British Library (London) Harley 405. Folio 42-61.

BD-4 BARANYAI DECSI, János:

Syntagma institvtionvm ivris Imperialis ac Vngarici, qvatvor perspicvis qvestionvm ac responsionvm libris comprehensvm opera ac stvdio Ioannis Decii Barovii. - Typis Heltanis, Claudiopoli Transyluanie (Kolozsvár) 1593. (12) + 61 fol $+667 \mathrm{p}+10$ fol. $4^{\circ}-(\mathrm{RMNy}-719)$.

BD-5 BARANYAI DECSI, János:

Regvlarum ivris et sententiarvm centvriae sex. - Syntagma institvtionvm ivris (BD-4) pp. 619-667.

BD-6 BARANYAI DECSI, János:

Levél Hunyadi Ferenchez. (Letter to Ferenc Hunyadi.) Székelyvásárhely 16th Aug., 1596 - Hungarian translation in KJ pp. 19-21, and in JP pp. 804-807. (Translated by Ferenc CsONKA).

BD-7 BARONYAI DETSI, János:

(Translation of Salluste into Hungarian): Az Caivs Crispvs Salvstiusnac ket Historiaia. Elseo. Lvcivs Catilinanac, az Romai birodalom ellen valo orßag arulasarul (1-51. fol). - Masodic. Az nvmidiai Ivgvrta kiralynac, az Romaiak ellen viselt hadarul: (1-97 fol). Had viselöknec, es minden renbeli (sic!) embereknec haßnokra, deakbol magyarra fordittatot Baronyai Detsi Janos altal. Cvm gratia et privilegio Illustrißimi Principis Transiluaniae \&c. Ad decennium. - Nyomtattatot Szebenben, Fabricius Ianos altal. 1596. (5) $+51+97$ fol. $-8^{\circ}-(\mathrm{RMNy}-786)$.

Reprint: Bibliotheca Hungarica Antiqua X. - Akadémiai Kiadó, Budapest 1979. (Including a 31 page study by Ágnes KURCZ.)

BD-8 BARANYAI DECSI, János:

Commentarii de rebus Vngaricis (libri qvi exstant). - ToLDY, Ferencz (ed.): Baranyai Decsi János magyar históriája (1592-1598) - Eggenberger Ferdinánd Magyar Akad. Könyvárus, Pest 1866. pp. 1-328 - Hungarian translation: KULCSÁR, Péter (ed): Baranyai Decsi János magyar históriája (1592-1598) - Európa Könyvkiadó - Helikon Kiadó, Budapest, 1982. Péter KulCSÁR: Introduction: pp. 5-26. - Hungarian translation of the history: pp. 27-394. - Notes by Ibolya BELLUS: pp. 395414.

BD-9 BARANYAI DECSI, János:

A török elleni harcra buzdító beszéd 1598-ból. - Oratio Ioannis Decii Baronii ad Serenissimum Principem ac Dominum Dominum Sigismundum Dei gratiae Transilvaniae, Moldaviae ac Transalpinae Walachiae, Sacrique Romani Imperii Principem. Equitem Aurei velleris partium Regni Ungariae Dominum ac Siculorum Comitem. De bello adversus Turcam fortiter et constanter persequendo. (1598) - BALÁZS, Mihály - MONOK, István - VARGA, András - (TAR, Ibolya, transl.): Lymbus Múvelődéstörténeti Tár II. József Attila Tudományegyetem Központi Könyvtár (Central Library of József Attila University) Szeged, 1990. pp. 37-100. (BERLÁsz: Országos Széchényi Könyvtár Évkönyv - Yearbook of the National Széchényi Library 1972 (1974) pp. 218228.)

BD-10 BARANYAI DECSI, János - Joannes Decius BAROviUS:

(Epistola) Joanni Telegdio S.P.D. Datum ex Foro Siculorum, D. 5. Martii A. MDXCVIII. (1598) F(ELSŐ) Ts(ERNÁTONI) BOD, Péter: Magyar Athenas. (Sárdi Sámuel, Szeben) 1766. 4-(6)r fol. (In the chapter: A Hazádat és magyar nemzetedet igazán szerető kegyes olvasó) - Also in JP pp. 807810. (Translation by Ferenc CSONKA.), and TF pp. LXVIII-LXXI. 
BD-11 BARANYAI DECSI, János:

Poems - Versek: 1. Dedication of the Hodoeporicon to Farkas Losonci Bánffy (Latin, Wittenberg 1587. Iohannes $C z$. Deczi, 12 lines) RMK-III. 764. - (Hungarian translation by István TóTH: KSI pp. 247-248). - 2. To Miklós Debreceni Tankó - (Greek, Wittenberg 1588. Iohannes Cz. Decius) RMKIII. 777. - 3. To János Tolnai Szabó (Latin, Wittenberg 1588. Iohannes C. Deczi) RMK-III. 781. - 4. To Mihály Forgách (Latin, Wittenberg, 1589. Ioannes Deczius) RMK-III. 794. - 5. To Demeter F. Eszlári (Latin, Wittenberg 1589. Ioannes Cimor Deczius) RMK-III. 795. - 6. To Zsigmond Újfalusi Pécsy (Latin, Wittenberg 1589. Iohannes Deczius Ungarus) - RMK-III. 798. - 7. To András Reichmund (Latin, Strassburg 1591. Ioan. Deczius) RMK-III. 814. - 8. Elegia IX. Manes Sturmiani sive Epicedia scripta in obitvm svmmi viri D. Ioan. Sturmii ... (Iosias Rihelius, Argentinae - Strassburg 1590. Ioannes C. Deczius Vngarus) $\mathrm{H}_{1}$ b- $\mathrm{H}_{2}$ a. - RMK-III. 807/a - 9. Fide Deo, diffide tibi ... Syntagma institvtionvm ivris Imperialis ac Vngarici (Kolozsvár 1593, Ioannes Decius Barovius) (RMNY-719) (BD-4).

BD-12 (BARANYAI DECSI, János?):

Oratio De Constitvendo Ivdice Controversiarvm Religionis Pontificae Atque Reformatae: In qua declaratur: Primvm cvr non Pontifices Romani, Secundo cur non concilia, Tertio cur non veteres Patres, Quarto cur non traditiones, Quinto cur non Miracula, Sexto cur non ordinaria Pontificum Romanorum successio, Septimo cur non consensus in publica doctrina, Octavo cur non vetustissima consuetudo: Sed Solum Dei Verbum Scriptum possit ac debeat omnes Religionis controversias componere ... Scripta Et Habita ab Vngaro Veritatis Asserendae Stvdioso. Basileae 1591. 60 pp. (RMK-III. 810).

English translation by Richard Smith: The trial of truth or a treatise wherein is declared who should be judge betwene the reformed churches, and the Romish: in which is shewed, that neither pope, nor councels, nor fathers, nor traditions, nor succession, nor consent, nor antiquitie of costume: but onely written words of God ought to determine the controuersies of religion ... Published in Latine by a certain Hungarian, a favourer of the truth ... Robert Dexter, London 1591. 33 fol. (RMK-III. 5515).

BE BARTONIEK, Emma:

Baranyai Decsi (Csimor) János. - BARTONIEK, Emma: Fejezetek a XVI-XVII. századi magyarországi történetírás történetéből. (Chapters from the historiography in Hungary in the 16th to 17th centuries.) (Manuscript.) - MTA Irodalomtudományi Intézete - MTA Könyvtára, Budapest 1975. pp. 259-275.

BGy BARTS, Gyula:

Mikor halt meg Baranyai Decsi János? (When did János Baranyai Decsi die?) - Irodalomtörténet 4 (1915) 146.

BM-1 Dr. BALLAGi, Móric:

Magyar példabeszédek, közmondások és szójárások gyújteménye. Összeszedte, értelmezte és más nemzetek hasonértelmú mondataival fölvilágosította Dr. Ballagi Mór. Első kötet. A-N., (A collection of Hungarian proverbs and phrases, together with similar sentences of other nations...) Szarvason, Réthy Lipót nyomdájában 1850. (Önjelentés, a szerkesztőség kérésére.) - Új Magyar Múzeum (Pest), Első folyam, 1850-51, első kötet, II. füzet (Nov. 1. 1850), 125-128.

BM-2 BALlagi, Mór:

Magyar példabeszédek, közmondások és szójárások gyújteménye. Összeszedte, értelmezte és más nemzetek hasonértelmú mondataival fölvilágosította Dr. Ballagi Mór. 1-2. kötet. (A collection of Hungarian proverbs and phrases, together with similar sentences of other nations ...) Réthy Lipót nyomdája, Szarvas 1850.462 pp. (8313 items).

BM-3 BALLAGI, Mór:

Baronyai (sic!) Decsi János és Kis-Viczay Péter közmondásai. (The proverbs of János Baronyai Decsi and Péter Kis-Viczay) - Értekezések a Nyelv- és Széptudományok köréből 10, 5. füzet (1882) 15 pp.

BM-4 BALLAGi, Mór:

A magyar nyelv teljes szótára. 1-2. Rész. (A comprehensive dictionary of the Hungarian language.) Heckenast Gusztáv, Pest 1873. 672 + 775 pp. - (Reprint: Nap Kiadó Bt., Budapest, 1998).

BP F(ELSÓ) TS(ERNÁTONI) BOD, Péter:

Detzi Tzimor János. In: F. Ts. BoD, Péter: Magyar Athenas. (Sárdi Sámuel, Szeben) 1766. 68-69.

BU BLÄSING, Uwe:

Tschuwaschische Sprichwörter und sprichwörtliche Redensarten. Harrassowitz Verlag, Wiesbaden, 1994. 849 pp. (4396 items.). 
CzI CZEGLE, Imre:

Szárászi Ferenc: Erasmus Adagia 1559 (A translation of Erasmus’ Adagia into Hungarian). - A Ráday Gyújtemény Évkönyve 4-5 (1984-85) 124-134.

CsI CSELKÓ, István:

Magyar közmondások. (Hungarian proverbs.) - CSELKÓ, István: Válogatott darabok minden korú jeles magyar írókból. Az ifjúság hasznára. - Belnay özvegy és örökösei, Posonyban, 1817. pp. 123154.

DÁ-1 DANKANITS, Ádám:

Erasmus erdélyi olvasói. (The readers of Erasmus in Transylvania.) - Nyelv- és Irodalomtudományi Közlemények 11 (1967) 125-131.

DÁ-2 DANKANITS, Ádám:

XVI. századi olvasmányok (Erdélyben). (Books read in Transylvania in the 16th century.) - Kriterion, Bucharest, 1974.

DL DÉZSI, Lajos:

Szenczi Molnár Albert naplója, levelezése és irományai. (The diary, correspondence and writings of Albert Szenci Molnár.) - MTA, Budapest, 1898. p. 9.

EAd ERASMUS, Desiderus:

Des. Erasmi Roterodami Adagiorvm Chiliades qvatvor cvm sesqvicentvria, ex postrema authoris recognitione ... Ex Officina Episcopiana, per Eusebium Episcopum et Nicolai Fr. haeredes, Basileae MDLXXIIII (1574) - (116) $852+647+(86)$ pp. $-2^{\circ}-$ After the $852 \mathrm{p}$ text of ERASMUS (Numbers 1.1.1.1.-5.2.5.1.): Typographus lectori (columns 1-96), Adagiorum Appendix ex Erasmi Chiliadibus ad studiosum commoditatem excerpta (p 97-109, items 1-160) the collections of Hadrianus IUNIUS (pp. 109-288, 840 items), Johannes Alexander BRASSICANUS, (pp. 288-308, 146 items), Johannes UlPIUS (pp. 308-316, 127 items), Gilbert COUSIN (COGNATUS) (pp. 316-602, 1810 items), Ludovicus Caelius RHODIGINUs (pp. 602-606, 53 items), Polydorus VERGILIUS (pp. 606-610, 60 items), Petrus Godofredus (pp. 610-613, 36 items), Charles de Bovelles (pp. 613617, 47 items), Adrianus TURNEBUS etc. (pp. 617-620, 30 items), Gulielmus GENTIUS (pp. 620-624, 50 items), Specimen quoddam adagiorum quae ab JUNIO, CANTERO et GISELINO ... collecta sunt ... (pp. 625-632, 49 items), and Adagia of Melchior NEIPEIUS (pp. 632-647).

EEp ERASMUS, ROTERODAMUS:

Epitome adagiorvm Graecorum \& Latinorum iuxta seriem Alphabeti. Ex Chiliadibus Eras. Roterodami. - (Honter, Corona - Brassó -) MDXLI (1541) - 56 fol. (RMNY-43).

EJ ERDÉLYI, János:

Decsi Csimor János - In: ERDÉLYI, János: A hazai bölcsészet múltja. 8. A bölcsészet Magyarországon. Első könyv, ötödik fejezet (The past of Hungarian philosophy. 8. Philosophy in Hungary. Vol. 1. Ch. 5). In: ERDÉLYI, János: Filozófiai és esztétikai írások (Philosophical and aesthetical writings). (ed. T. ERDÉLYI, Ilona) Akadémiai Kiadó, Budapest, 1981. pp. 236-241.

EJ-1 ERDÉLYI, János:

Magyar közmondások könyve. (A book of Hungarian proverbs.) - Kozma Vazul, Pest 1851. 462 pp. (9000 items).

EJ-2 ERDÉLYI, János:

Válogatott magyar közmondások. (Selected Hungarian proverbs.) - Heckenast Gusztáv, Pest 1862. 255 pp. (7362 items).

ÉSz BÁRCZI, Géza-OrSZÁGH, László (eds.):

A magyar nyelv értelmezó szótára. I-VII. kötet. (The monolingual dictionary of the Hungarian language. Vols. I-VII.) Akadémiai Kiadó, Budapest 1959-1962.

FE FORGÁCHNÉ DRAHOTA-SZABÓ, Erzsébet:

Szólások és közmondások vizsgálata Heltai Gáspár múveiben. (A study of sayings and proverbs in the works of Gáspár Heltai.) Thesis, József Attila University, Szeged, 1985. (Szólás- és közmondásszótár [Dictionary of sayings and proverbs] p. 80.)

FV Fasciculus Vocabulorum, Sententiarum et Adagiorum. A 17th cent. manuscript in the National Széchényi Library, Budapest. (Duod. Hung. 51.)

GGy GÖMÖRI, György:

Magyar szerzók múvei a XVI. század végi Angliában. (Works of Hungarian authors in England at the end of the 16th century.) - Magyar Könyvszemle 96 (1980) 4. 391-393.

JLH HAWENREUTER, Johannes Ludwig:

Adagia classica scholis Argentinensibus digesta. - Excudebat Iosias Rihelius, (Argentorati) 1573. a $+302+(5)$ pp. $-8^{\circ}$. 
JP Janus Pannonius - magyarországi humanisták. (Janos Pannonius - Humanists in Hungary.) (Magyar remekírók) Szépirodalmi Kiadó, Budapest 1982. 1412 pp.

KÁ KuRCZ, Ágnes:

Baranyai Decsi János magyar Sallustiusa. (The Hungarian Sallust of János Baranyai Decsi.) - Irodalomtörténeti Közlemények 70 (1966) 1-2. 180-181.

Baranyai Decsi János Sallustius-fordítása. (Kíséró tanulmány a hasonmás kiadáshoz. A study attached to the reprint edition.) Akadémiai Kiadó, Budapest 1979. 31 pp.

KF KOVACSÓCZY, Farkas (1540-1594):

De administratione Transylvaniae dialogvs. (Adiecta est ad maximum et victorem Poloniae regem gratulatio.) - Heltai Gáspár, Kolozsvár 1584. 34 fol. (RMNy-545). - Hungarian translation by György BÓNIS: Dialógus Erdély igazgatásáról. JP, pp. 1225-1254., Notes: pp. 1335-1336.

KG KATHONA, Géza:

Tolna reformációja és iskolája. - Baranyai Decsi (Csimor) János és Laskai János. (The Reformation and the school of Tolna, János Baranyai Decsi Csimor and János Laskai.) - KATHONA, Géza: Fejezetek a török hódoltsági reformáció történetéből. (Chapters from the history of Reformation under Turkish rule). Humanizmus és reformáció 4. (Humanism aud Reformation 4.) - Akadémiai Kiadó, Budapest 1974. pp. 9-31, 77-79.

KI KNIEZSA, István:

A magyar helyesírás története. (The history of Hungarian orthography.) 2. kiad. (2nd edition), Tankönyvkiadó, Budapest 1959. p. 23.

KJ KonCZ, József:

Decsi Csimor János. In: KonCZ, József: A Marosvásárhelyi Evang(éliumi) Reform(átus) Kollégium története. Különlenyomat a Kollégium 1883-1888. és 1894-1895 iskolai évi Értesítőiből. (History of the Marosvásárhely Evang(elical) Reform(ed) College. Reprint from College Reports 1883-1888 and 1894-1895) - Sztupjár István, Ref. Kollégium, Marosvásárhelytt 1896. pp. 15-29. (National Széchényi Library 274881).

KM KISBÍRÓ, Márton:

Közmondások Szenczi Molnár Albert szókönyvéból. (Proverbs from the dictionary of Albert Szenci Molnár.) (Dictionarium Ungarico-Latinum, Hanau 1611.) - Magyar Nyelvőr 11 (1882) 327-329, 378-380, 428-429, 473-475.

KN KÖNNYE, Nándor:

Közmondások Decsi János “Adagia”-jából. (1598) (Proverbs from the Adagia of János Decsi.) Magyar Nyelvőr 11 (1882) 87-88, 176-177.

KO KELÉNYI, B. Ottó:

Egy magyar humanista glosszái Erasmus Adagiá-jához. (The glosses of a Hungarian humanist to the 1508 edition of the Adagia of Erasmus.) - Tanulmányok XIII. A Fóvárosi Könyvtár Évkönyve (Yearbook of Budapest Municipal Library) 9, 1939 (1940) (Reprint) 99 pp.

KP KOVÁcs, Pálnak Magyar Példa és Köz Mondási. (The Hungarian proverbs of Pál Kovács.) - Streibig József, Győr 1794, 235 pp.

KSI KovÁCS, Sándor Iván (ed.)

Magyar utazási irodalom. 15-18. század. (Hungarian writings on travels from the 15th to the 18th centuries.) Szépirodalmi Könyvkiadó (Magyar remekírók), Budapest 1990. pp. 247-264, 853-855 (Notes) (A full translation of the Hodoeporicon with the exception of the poem at the end by János CSANÁDI.)

KV KIS-VICZAY, Petrus:

Selectiora Adagia Latino-Hungarica in gratiam \& usum Scholasticae juventutis collecta et in alphabeti seriem concinnata ... Studio \& vigilantia Petri Kis-Viczay p.n. Eccl. Aug. Conf. Cassov. Nat. Hung. Past. - Typis Civitatis, Bartphae 1713. 552 pp.

LJ LuGOSSY, József:

Pótlékjegyzet az Új Magyar Múzeum II. füzetében megjelent "Dr. Ballagi Móric önjelentéséhez". (Addenda to the paper of Móric Ballagi.) - Új Magyar Múzeum, Elsô folyam, 1850-51, első kötet, V. füzet, p. 304. (1st Feb. 1851).

ME MARGALITS, Ede:

Magyar közmondások és közmondásszerü szólások. (Hungarian proverbs and proverbial phrases.) - Kókai Lajos, Budapest 1897. 770 pp. (25336 data) (Reprint: Akadémiai Kiadó, Budapest 1990 and 1995.)

NP-1 NAGY, Pál (ed.):

Erős várunk. Kollégiumi emlékkönyv. (Our stronghold. College memorial book.) - Custos Kiadó, Marosvásárhely 1993. 230 + XVIII pp + ill. 
NP-2 NAGY, Pál:

Baranyai Decsi Czimor János, egy erdélyi humanista. (János Baranyai Decsi Czimor, a humanist from Transylvania.) - Nyelvünk és Kultúránk, No. 98. 124-127. (Apr.-Aug. 1997).

ON-1 O. NAGY, Gábor:

Magyar szólások és közmondások. (Hungarian sayings and proverbs.) - Gondolat Kiadó, Budapest 1966. 864 pp. (Introduction: pp. 7-29, proverbs: pp. 31-736.) (There are several reprints since 1966.)

ON-2 O. NAGY, Gábor:

A magyar frazeológiai kutatások története. (The history of the research in Hungarian phraseology.) (ed.: KovALOvsZKY, Miklós) - Nyelvtudományi értekezések (Essays on Philology) 95. - Akadémiai Kiadó, Budapest 1977. pp. 15-21.

PF POMEY, François Antoine:

Idiotismi Hungarici Adagiales, qui nisi circumlocutione aliqua hungarice reddi nequeunt. - In: (Pomey, François Antoine): Syntaxis Ornata, seu de Tribus Latinae linguae virtutibus, puritate, elegantia, copia. In usum Mediae \& Supremae Grammaticae Classis studiosorum. Typis Academicis Societatis Jesu, Tyrnaviae (Nagyszombat) Anno 1745. pp. 60-62. (There are several reprints, e. g.: Nagyszombat: 1748, 1754, Kolozsvár: 1772, Buda: 1792).

Manuale (Reprinted in 1782)

PGy-1 PACZOLAY, Gyula:

European proverbs in 55 languages with equivalents in Arabic, Persian, Sanskrit, Chinese and Japanese - Európai közmondások 55 nyelven, arab, perzsa, szanszkrit, kínai és japán megfelelókkel. Veszprémi Nyomda Rt., Veszprém 1997. 528 pp.

PGy-2 PACZOLAY, Gyula:

A magyar közmondások és szólások kelet-európai rokonsága. (Hungarian proverbs with affiliations in Eastern Europe.) - Acta Hungarica (Ungvár-Uzhgorod) 6 (1995) 62-68 (Published in 1997).

PGy-3 PACZOLAY, Gyula:

A magyar közmondások és szólások nemzetközi rokonsága. (Affiliations of Hungarian proverbs.) Acta Hungarica (Ungvár-Uzhgorod) 4-5, (1993-1994) 36-51. (Published in 1997).

PPB PÁPAI PÁRIZ, Ferenc - BOD, Péter:

Dictionarium Hungarico-Latinum. Olim magna cura a clarissimo viro Alberto Molnár Szentziensi collectum, tandem revisum \& aliquot vocabularum, in Molnarino desideratum, millibus Latine redditis locupletatum, studio \& vigiliis Francisci PÁRIZ PÁPAI, Medicinae Doctoris, \& in Alma Enyedina Publici Professoris ... Opera Petri BOD de F(Elsô) TSERNÁTON, V. D. Ministri M(agyar) Igeniensis. Novae huic editioni nunc secundo solertia Typographi addita est Lingva Germanica. Sumptibus Martini Hochmeister Caes. Reg. Typographi \& Bibliop. Cibinii (Nagyszeben) Anno MDCCLXVII (1767). $404+2$ pp - (Part II. of the Dictionarium Manuale Latino-Hungaricum ... Proverbiis selectioribus interspersis ... 1767.) (Reprinted in 1782).

RMK-III SZABÓ, Károly-HELLEBRANDT, Árpád:

Régi magyar könyvtár III-dik kötet. Magyar szerzőktől külföldön 1480-tól 1711-ig megjelent nem magyar nyelvú nyomtatványoknak könyvészeti kézikönyve. Első rész. (Bibliography of prints by Hungarian authors, published abroad in foreign languages between 1480 and 1711. Part 1.) Hungarian Academy of Sciences, Budapest 1896. (Nos 1-2547).

Régi magyar könyvtár III. kötet. Pótlások, kiegészítések, javítások. 1. Füzet. (1471-1604) (Addenda and corrections to RMK-III) - National Széchenyi Library, Budapest 1990. (Nos 5001-5692).

RMNY BORSA, Gedeon et al. (eds):

Régi magyarországi nyomtatványok. 1473-1600. - Res litteraria Hungariae vetus operum impressorum. 1473-1600. (Old prints from Hungary 1473-1600) - Akadémiai Kiadó, Budapest 1971. 928 pp. (Nos. 1-869) - Vol. 2. 1601-1635. - Budapest 1983. 856 pp. (Nos. 870-1632).

SF FRANCK, Sebastian:

Sprichwörter, Schöne, Weise, Herzliche Clugreden unnd Hoffsprüch, Darinnen der alten und nachkommenen aller Nationen unnd Sprachen gröste vernunfft unnd klugheyt. ...Beschriben ... Durch Sebastian FRANCKEN. Getruckt ... Bey Christian Egenolffen, Franckenfurt am Meyn 1541. 163 fol +211 fol.

SNG SÁNDOR Mihályné NAGY Gabriella:

Székely közmondások. (Sekler proverbs.) (Magyar Csoportnyelvi Dolgozatok 44.) (Institute for the History and Dialects of the Hungarian Language, Lóránd Eötvös University, Institute of Philology, Hungarian Academy of Sciences.) Budapest 1990. 48 pp.

SzA SzABÓ, András (ed.):

Johann Jakob Grynaeus magyar kapcsolatai. (Hungarian relations of Johann Jakob Grynaeus) 
(Adattár XVI-XVIII. századi szellemi mozgalmaink történetéhez. Thesaurus to the History of Our Spiritual Movements in the XVI-XVIII. centuries, 22.) - József Attila University Szeged 1989. pp. 51-59. (Letters XXII-XXVI, Strassburg 31 May 1590, 26 Feb. 1591, 12 May 1591, 28 June 1591, 5 Feb. 1592.) - Notes: pp. 140-143.

SzG SzABÓ, Géza:

Geschichte des ungarischen Coetus an der Universität Wittenberg 1555-1613. - (Bibliothek des Protestantismus im mittleren Donauraum 2.) - Halle/Saale 1941.

SzK SZEGEDI KIS, István:

Theologiae Sincerae Loci Communes De Deo Et Homine (cum Confessione de Trinitate) ... Tabvlis \& Scholasticorvm dogmatis illustrati Per Stephanvm Szegedinvm Pannonivm. Cvm Indicibvs Rerum \& Verborum Locorumque Sacrae Scripturae explicatorum locupletissimis. Ex Officina Pernea, per Conradvm Waldkirch, Basileae 1585. 506 pp +28 fol., 1588. 665 pp + 45 fol., 1593, 665 pp +31 fol., 1599. 665 pp +45 fol., 1608. 665 pp +41 fol. (RMK-III. 740, 772, 832, 932, 1052).

SzM-1 SzEnCI MOLNÁR, Albert:

Dictiones Ungaricae, summo studio collectae et Latine conversae, iuxtaque ordinem literarum, prout scribi solent, digestae, nunc denuo diligenter emendatae, plurimus vocibus formulisque loquendi Latine redditis auctae: et usitatioribus Proverbiis Ungaricis, cum Latinis Adagiis aequipollentibus locupletatae, quae ad initialem vel praecipium Adagionis Ungaricae vocem facile invenientur. Auctore Alberto MolnAR SzENCIENSI. - Typis Thomae Villeriani, Hanoviae (Hanau), MDCXI (1611) 335 pp. - (Part II. of the Lexicon Latino-Graeco-Hungaricum.) (RMNY-1012).

SzM-2 SZENCI MOLNÁR, Albert:

Dictionarium Ungarico-Latinum. Innumeris vocibus Ungaricis, formulisque loquendi Latine redditis, Nunc tertium locupletatum: cui inspersa sunt usitatiora Proverbia Ungarica, cum aequipollentibus Adagiis Latinis: quae omnia sub initiali, vel praecipua Adagionis Vngaricae voce facile reperiuntur. Authore Alberto MolnAR SzenciensI. Typis Viduae Joh. Georgii Geyderi Acad. Typogr., Heidelbergae, Anno MDCXXI (1621) - 368 pp. - (Part II. of the Lexicon Latino-Graeco-Ungaricum) (RMNY-1239). (Reprint: Frankfurt, 1644. RMNY-2099).

SzM-3 SZENCI MOLNÁR, Albert:

Dictionarium Ungarico-Latino-Germanicum, innumeris vocibus Ungaricis formulisque loquendi Latine redditis, Nunc quarta vice locupletatum. Cui inspersa sunt usitatiora Proverbia Ungarica, cum aequipollentibus Adagiis Latinis: Quae omnia sub initiali, vel praecipua Adagionis Ungaricae facile reperiuntur. - Autore Alberto MolnAR SzENCIENSI, Sumptibus Martini Endteri, Noribergae (Nürnberg), Anno MDCCVIII. (1708) 576 pp. (Part II. of the Dictionarium Quadrilingue LatinoUngarico-Graeco-Germanicum.) (RMK-I. 1749).

TCs BARANYAI DECSI, János (?):

(Török császárok krónikája. Chronicle of Ottoman Rulers.) - KLANICZAY, Tibor - STOLL, Béla (eds.): Régi magyar költők tára. (Collection of old Hungarian poets). XVII. century, Vol. 1. Akadémiai Kiadó, Budapest 1959. pp. 86-102. (lines 1-846. - 1597) - Szeben 1597-1599. (RMNY842).

TF TOLDY, Ferencz:

Baronyai Decsi János magyar históriája (1592-1598) a szerzó életével (és képével). (The 1592 to 1598 history of Hungary by János Baronyai Decsi, together with the biography - and picture - of its author.) - Ferdinánd Eggenberger, Pest 1866. LXXX (Decsi János élete és munkái) + 328 pp. (Ioannis Decii Barovii Commentariorum de Rebus Vngaricis Libri qui exstant, including: Praefatio ad Serenissimum Principem Sigismundum - pp. 3-10.)

TG TÖRÖK, Gábor:

Adalékok a liquidák nyújtó hatásának jelentkezéséhez. - (Addenda to the prolonging effect of liquids.) - Magyar Nyelv 50 (1954) 32-37.

TL-1 TARDY, Lajos:

Baranyai Decsi Czimor János Hodoeporiconja (1587). (The Hodoeporicon of János Baranyai Decsi Czimor. - 1587 -.) - Filológiai Szemle 11 (1965) 3-4. 359-371.

TL-2 TARDY, Lajos: Erdélyi diákok utazása 1587-ben. (A travel of Transylvanian students in 1587.) In: TARDY, Lajos: Régi hirünk a világban. (Our old fame in the world.) Gondolat Kiadó, Budapest 1979. pp. 109-118.

TV-1 TOLNAI, Vilmos:

A szólásokról. Adalék a szóláshasonlatok, szólásmódok és közmondások elméletéhez. (On proverbs. Addenda to the theory of proverbial comparisons, sayings and proverbs.) (Inaugural lecture at the 
March 22, 1909 session of Section I of the Hungarian Academy of Sciences.) (Publications of the Hungarian Philological Society 12.) - Hungarian Philological Society, Budapest 1910. p. 23-41. (Also in: Magyar Nyelv 5 (1909) 396-401.

TV-2 TOLNAI, Vilmos:

Decsi János Adagiumainak forrása. (The source of the Adagia of János Decsi.) - Magyar Nyelv 7 (1911) 223-224.

VF VERSEGHY, Ferenc:

Adagia. In: VERSEGHY, Ferenc: Exercitationes idiomatis Hungarici secundum regulas epitomes concinnatae in usum gymnasiorum Regni Hungariae. - Typis Regiae Universitatis Hungaricae, Budae 1822. pp. 124-144.

VG-1 Vöő, Gabriella:

Igaz ember igazat szól. Közmondások a romániai magyar folklórból. - (A true man tells the truth. Proverbs from the Hungarian folklore in Romania.) Kriterion Kiadó, Bucuresti 1989. 316 pp. (Introduction: 5-38, proverbs: 39-278).

VG-2 VÖŐ, Gabriella:

Szaván fogjuk. Erdélyi magyar szólások. (You are taken by your word. Hungarian sayings from Transylvania.) - Erdélyi Gondolat Könyvkiadó (Transylvanian Thought Publisher) Székelyudvarhely, 1999. 372 pp. (Introduction: 3-19., sayings: 20-348).

WF WAGNER, Ferenc:

Universae phraseologiae Latinae corpus congestum a P. Francisco WAGNER, Societatis Jesu Sacerdote, secundis curis a quopiam ejusdem societatis Sallustiana, Caesareana, Liviana, Corneliana \&c. Phraseologiis, demum apud nos linguis Hungarica \& Slavica, locupletatum. - Typis Academicis Societatis Jesu - (Tyrnava - Nagyszombat) - Anno MDCCL - (1750) - 1272 pp. (Reprint: 1775). Universae phraseologiae Latinae corpus congestum a P. Francisco WAGNER, Societatis Jesu Sacerdote, secundis curis a quopiam ejusdem societatis Sallustiana, Caesareana, Liviana, Corneliana \&c. Phraseologiis, demum apud nos linguis Hungarica \& Slavica, locupletatum. Editio Tyrnaviensis altera. - Typis Tyrnaviensibus - (Tyrnava - Nagyszombat) - Anno MDCCLXXV - (1775) - 1272 pp.

ZJ-1 ZLINSZKY, János:

Ein Versuch zur Rezeption des römischen Rechts in Ungarn. - In: Franz HORAK - Wolfgang WALDSTEIN (Hrsg.): Festgabe für Arnold Herdlitczka zu seinem 75. Geburtstag. - Wilhelm Fink, München/Salzburg 1972. pp. 315-326.

ZJ-2 ZLINSZKY, János:

Vita et opera Joannis Decii Barovii. - Publicationes Universitatis Miskolciensis, Sectio Juridica et Politica 7 (1992) 207-214.

ZsJ ZsigMOND, József:

Közmondások és szólások (Magyarón). (Proverbs and sayings in Magyaró.) - In: ZsiGMOND, József, PALKÓ, Antal: Magyaró néphagyományaiból. Szemelvények. (A selection from the popular traditions of Magyaró, a village in Transylvania.) Mentor Kiadó, Marosvásárhely, 1996. pp. 97-116. 